\title{
RPA2 wt Allele
}

National Cancer Institute

\section{Source}

National Cancer Institute. RPA2 wt Allele. NCI Thesaurus. Code C116635.

Human RPA2 wild-type allele is located in the vicinity of $1 \mathrm{p} 35$ and is approximately $23 \mathrm{~kb}$ in length. This allele, which encodes replication protein $\mathrm{A} 32 \mathrm{kDa}$ protein, plays a role in DNA replication, repair and recombination. 